\title{
Literature Study on Building a Model Support for Children with Learning Disabilities in Indonesia
}

\author{
Lily Eka Sari \\ Petra Christian University, Jl. Siwalankerto 121-131, Surabaya 60236, Indonesia
}

Keywords: learning disabilities; children; challenges; needs

Abstract: Learning Disabilities are typically detected when children reach school age. It is the period when certain targets demands are placed; whereas the children's abilities to process cognitive and social skills are different compared to their peers. This study is intended to 1) map out the types of Learning Disabilities commonly found in elementary schools; 2) describe the children's challenges and needs in the learning process; and 3) suggest adaptations and modifications necessary to support their learning processes. The findings show that the school system has already made efforts despite the lack of information and teachertraining programs in this area. This study would be a great reference for educators and families with diverse abilities, especially in Indonesia.

\section{INTRODUCTION}

Elementary School system in Indonesia under Public Law (Undang-Undang) 2003 No.20 provides education for children, including those who have special needs. Schools all over Indonesia are facing the challenges to serve students with various styles, modes, and speed of learning.

This paper is a literature study of the types of Learning Disabilities which are commonly found in Elementary School students, the challenges and needs in the learning process, as well as suggestions regarding adaptations and modifications which might help them. Data and information are derived from scholarly journals and textbooks.

\section{TYPE OF LEARNING DISABILITIES}

Learning Disabilities is unique. It is often undetected and undiagnosed. It is often mislabeled as merely lazy, bad behaviors, or even stupid. Students who have Learning Disabilities (LD) are often underserved in the school systems due to the lack of teacher training and information in this subject. In fact, as more scholar conduct researches in this area, the definition of LD might evolve and expand over time.
The term Learning Disabilities (LD) was written in 1968 by the National Advisory Committee on Handicapped Children, which then was slightly adapted for Individuals with Disabilities Education Act (1990) . IDEA defines the term as "a disorder in one or more of the basic psychological processes involved in understanding or in using language, spoken or written, that may manifest itself in an imperfect ability to listen, think, speak, read, write, spell or do mathematical calculations, including conditions such as perceptual disabilities, brain injury, minimal brain dysfunction, dyslexia, and developmental aphasia" (National Dessemination Center For Children, 2004).

The definition above gives us quite a clear description that there are several areas affected by the children's inability to process. These limitations might result in moderate to severe academic issues. The next part of this paper shall discuss the challenges and needs imposed to the students as they struggle with the traditional school systems in Indonesia.

\section{CHALLENGES AND NEEDS}

Fo There are little studies, publications and regulation from the government of Indonesia when it comes to individuals with LD. In terms of services 
for students with disabilities, the terms are restricted to those who have physical and developmental disabilities. This is shown from the official publication released by the Center of Data and Information of the Ministry of Health, Republic of Indonesia (InfoDATIN, 2004). While mapping out the prevalence of disabilities in Indonesia, there is no referral to Learning Disabilities. Studies on medical services for individuals with LD in the United Kingdom also links this tendency to the lack of healthcare and social services (Russell, Bryant, and House, 2017).

The underrepresentation of LD in the school systems and teacher preparation programs might lead us to several issues. First, without proper diagnosis and identification, the individuals with LD might be misjudged. They will carry out negative labels such as: incompetent, unmotivated, and underachievers. Unfortunately, those labels would likely only lead the students to negative behavior problems. There should be further researches to link those antecedents to the actual behavior issues, along with the consequences imposed to the students in Indonesian school systems. Second, without proper official reports and studies in this area, it is hard for teachers to plan, implement and evaluate teaching processes for students with LD.

This paper will discuss three basic skill areas. These areas will likely affect other types of learning as well. Hunt and Marshall describe the key processes which are involved in cognition. They are: reading, language arts, and mathematics (Hunt and Marshall, 2005).

\section{READING}

One of the objectives of the subject of Bahasa Indonesia is to read properly and to comprehend the text (Janurti, Dibia, Widiana, 2016). Most of the learning processes in Indonesian school systems require students to achieve high level of reading and comprehension. Students who experience difficulties in reading often experience difficulties in other subject areas, too (Hunt and Marshall, 2005). There are students who have difficulties comprehending content areas of other subjects due to the novel terms which might be challenging to pronounce and comprehend (Kang, et.al, 2015).

Unfortunately, students with LD struggle the most with reading skills (Hunt and Marshall, 2005). Students with LD who show specific reading difficulties is associated with dyslexia. It may refer to specific and severe to more generalized reading disabilities (Hunt and Marshall, 2005). Due to their condition, those students tend to lose interest in reading, which may progressively delay their reading skills.

Reading requires the abilities of word analysis, fluency, and comprehension (Hunt and Marshall, 2005). Regardless the lingua franca, reading involves phonic analysis, which include the ability to associate sounds and letters (Hunt and Marshall, 2005). The discomfort of oral reading problems in the early school years, combined with the problems to answer comprehension questions, might cause reluctance for the students to read more.

Furthermore, reading skills might be in direct alignment with writing skills. Studies show that, in grade 2 and 5, reading could be applied to writing; whereas, writing skills could support reading (Kang, et.al, 2015). In this case, students who are not motivated to read more, are likely to show interest in putting their thoughts into writing. In fact, assessments and evaluations in Indonesian school systems are largely conducted through written tests. This tendency would significantly affect those students' academic performance.

\section{LANGUEAGE ARTS}

One Each language requires moderate to intermediate spellings skills. The skills to spell words involve word-analysis strategies of phonics and sight-word reading (Hunt and Marshall, 2005). In some subject areas, the problem to process language might become a barrier. For example, the subject of science has shifted from traditional textbook approach to inquirybased instruction, in which students become the central drive in the learning process (Kaldenberg, et.al, 2014). However, despite such shift, students are still required to read texts, comprehend the process, and then compose a report.

In several areas, the ability to speak fluently could hide the fact that actually the individual has problems with processing language. Since the individuals could answer questions orally, they are not eligible for services under diagnostic criteria such as DSM-V, which is more geared towards the general population (Welsh and Morrison, 2017).

\section{MATHEMATICS}

Mathematics is a rich subject. It does not involve only computation skills, but also other skills such as 
the abilities to estimate, make predictions, and problem-solving. Students with LD show difficulties in translating problems into numeric execution, which is rooted in their language-based disabilities (Sharp and Dennis, 2016).

The delivery of mathematics in elementary schools have shifted towards the use of applications (Bryant, et.al, 2015). However, mathematics might present challenges for students with dyscalculia. Students with dyscalculia would likely show persistent problems with certain aspects of mathematics, such as the numeric comprehension.

\section{ADAPTATION AND MODIFICATIONS}

Considering the abovementioned description, it is sufficient to determine there are several types of LD which might occur in elementary school students in Indonesia. These types of LD interfere with their cognitive processes. Whereas, for the sake of time and energy limitations, teachers still rely on lecture and textbook-reading and writing in the teaching processes. It is not surprising to see that the academic achievement of students with LD show discrepancy between what they know and what they show. In other words, their academic performance does not necessarily reflect their actual abilities. Such reality should encourage teachers and scholars to make suggestions in terms of adaptation and modifications in the process of teaching and learning,

In terms of students who pose problems with language processing, Kaldenberg et al (2014) suggest content enhancement as part of the teaching and learning processes (Kaldenberg, et.al, 2014).

These techniques include adaptation and modifications such as mnemonic illustrations, the use of graphic organizers, visual representations, and the use of a semantic feature matrix. (Kaldenberg, et.al, 2014). These techniques should be used based on a solid baseline. They should be delivered by teachers who are highly trained in this area to avoid misuse and confusion.

Students with LD in mathematics might benefit from adaptation and modifications as well. When delivering the teaching materials, teachers might use manipulatives, for example, so the students can use their sensory and tactile abilities to comprehend the materials and solve the problems. Teachers might also use diagrams, or number lines to "reduce demands on working memory that inhibit the student's ability to flexibly process relationships among fractions" (Sharp and Dennis, 2016).. In other words, students with LD might benefit from learning process which are concrete and meaningful to them.

One of the problems which both students and teachers face is the type of assessment and evaluation. Either school wide or standardized, tests are still given in the form of reading and writing. Both areas are the major challenges for students with LD. Therefore, when conducting assessment and evaluation, teachers should keep an open mind to alternative types of assessments. This method might involve creating a project which does not rely on reading and writing, as well as observations which indicate that the students have shown mastery of the learning objectives. In fact, involving the students in the observation process might also help them with self-evaluation, self-regulation, and making prediction (Hunt and Marshall, 2005).

In some cases, the students' inability to process mathematical problems is so severe that interventions have little effects on them. Bryant et al (2015) argue that there is no significant difference when it comes to learning mathematics through application or teacher-delivered (Bryant, et.al, 2015).

In any case, teachers should consider making the Individualized Education Program (IEP) for each student who show problem in their classroom. This method requires trainings and background knowledge. However, when implemented, IEPs may lead to communication, collaboration, creativity, and critical thinking. IEPs should be included in the nationwide teacher training programs, particularly for elementary school teachers. That way, teachers have better understanding to tailor-made their teaching methods.

\section{CONCLUSION}

Education for students with Learning Disabilities require teachers' ability to identify the problems, make baseline, deliver the materials, and assessing students' progress in order to plan the next step. There should further researches and studies in terms of teaching students with Learning Disabilities. That way, more and more students get to experience the joy of learning, even by cherishing their different abilities 


\section{REFERENCES}

Individuals with Disabilities Education Act of 1990, 20 U.S.C. $\S 1400$ et seq.

National Dissemination Center for Children with Disabilities. 2004. Learning Disabilities. Disability Fact Sheet, no.7 (January). http://www.nichcy.org/pubs/factshe/fs7.pdf.

InfoDATIN. 2014. Penyandang Disabilitas pada Anak: 3 Desember-Hari Penyandang Cacad Sedunia. Pusat Data dan Informasi Kementerian Kesehatan RI.

Russell, A.M., Bryant, L., and House, A. 2017. "Identifying People with Learning Disabilities: An

Advanced Search for General Practice." British Journal of General Practice, December 2017: e842-e850.

Hunt, N. and K, Marshall.2005. Exceptional Children and Youth. 4th ed. Houghton Mifflin Co. pp. 116-165.

Janurti, N K., I K. Dibia, and I W. Widiana. 2016. "Analisis Kesulitan Belajar dalam Pembelajaran Membaca Cepat Siswa Kelas V SD Gugus VI Kecamatan Abang," e-Journal PGSD Universitas Pendidikan Ganesha Jurusan PGSD, 4(1):1-10.

Kang, E. Y., et al. 2015. "Integrated Reading and Writing Interventions for Students with Learning Disabilities: A Review of the Literature," Learning Disabilities Research \& Practice, 31(1):22-33.

Kaldenberg, E. et al. 2014. "Reading Instruction in Science for Students with Learning Disabilities: A Meta-Analysis," Learning Disability Quarterly, Hammill Institute on Disabilities: 1-14.

Welsh, H., and G. Morrison. 2017. "Learning Disability and the Scottish Mental Health Act," Advances in Mental Health and Intellectual Disabilities, 11 (2):117.

Sharp, E. and Dennis, M.S. 2016. "Model Drawing Strategy for Fraction Word Problem Solving of Fourth-Grade with Learning Disabilities," Remedial and Special Education:1-12.

Bryant, B. R., et al. 2015. "Performance of Fourth-Grade Students with Learning Disabilities on Multiplication Facts Comparing Teacher-Mediated and TechnologyMediated Interventions: A Preliminary Investigation," Journal of Behavior Education, 24:255-272. 